\title{
Secular Changes on Stature Reconstruction from Hand and Foot Dimensions among Sikhs of Delhi
}

\section{Suminder Kaur ${ }^{*}$ and Vineeta Saini}

Forensic Science Laboratory, Delhi, India

"Corresponding author: Suminder Kaur, Forensic Science Laboratory, Delhi, India, E-mail: ksuminder@gmail.com

Received date: January 05, 2016; Accepted date: April 25, 2016; Published date: May 2, 2016

Copyright: ( 2016 Kaur S, et al. This is an open-access article distributed under the terms of the Creative Commons Attribution License, which permits unrestricted use, distribution, and reproduction in any medium, provided the original author and source are credited.

\begin{abstract}
In forensic investigation, there are difficulties in stature and gender estimation of bodies dismembered in mass destruction and criminal mutilation. An individual's hand or foot, when recovered and brought for forensic examination, can provide valuable information about a person's identity. Stature provides insight into various features of a population, including nutrition, health and genetics, geographical location, environment and climatic condition.

Stature estimation remains a constant challenge for forensic anthropologists because of secular changes in stature due to allometric changes in long bones, and migrations of world populations. In the forensic literature a considerable attention has been paid in regard to stature estimation from long bones. But little attention has been received on secular changes in hand and foot dimensions in a homogenous population with similar climatic adaptation over the years.

The present study deals with the comparison of hand length and foot length along with stature among male and female Sikhs of the Delhi region in two different time frames i.e., 1998-2015 (16 years). Both studies were compared to see the secular changes in these parameters. The results show that in the year 2015, a negative secular trend is observed in the mean value of stature among both male and female Sikhs, thereby indicating their weaker socioeconomic, environmental and biological parameters. No marked secular changes have been observed in hand and foot dimensions over the years. This indicates that hand and foot dimensions are genetically driven as negligible differences could be observed in their mean values.
\end{abstract}

Keywords: Forensic anthropology; Stature; Hand length; Foot length; Multiplication factor; Linear regression equations; Sikh; Anthropometry; Secular changes/trend; Socio-economic; Environmental

\section{Introduction}

Stature estimation is one of the four attributes of the biological profile obtained from human skeletal remains, which is a standard procedure in the fields of forensic and biological anthropology, bioarchaeology and paleoanthropology, in order to gain biological insights into the individuals/populations studied. Stature helps a forensic scientist in narrowing down the pool of possibilities in the investigation process involving unknown commingled skeletal remains. It also provides insight into various features of a population, including nutrition, health and genetics.

Stature from feet dimensions plays a significant role in establishing personal identity. In India, the crime behavior is globalizing with very heinous approach to hide crime i.e., by dismembering body parts (recently more than 300 pieces) were found in a celebrity murder in Mumbai [1] and Nithari Murder case [2]. Cases that stimulate public curiosity present unique challenges to forensic practitioners in relation to the identification of the individual from whom the body part is originated. Further, the increasing frequency of mass disasters, homicides, air plane crashes, train and road accidents etc., there is always need for measuring body parts which help in identifying the deceased from fragmentary and dismembered human remains, beyond identification. It is very common to find the peripheral parts of the body such as hand and foot in such disasters. Hand and foot remain intact and thus in such a situation, their anthropometric or somatometric measurements provide good approximation about the height of a person [3-5].

Not just stature, hand prints and foot prints can be used to identify a criminal. Footprints are important evidentiary material found at various crime scenes [6], and detailed examination of footprints at the crime scene is an essential practice in criminal investigations. Footprints can provide information relating to the step length, position of each footprint, shape and size of the footprints and toes, ball lines, instep region, inner and outer margins, pits, injuries, and deformities. These individualistic and in-depth features of the footprints are likely to provide information regarding the stature, sex, body weight, and gait pattern of a person [7]. Hand prints or palm prints when present at the crime scene help us identifying the individuals that might have been involved in the crime. In cases of rape, burglary, homicide etc, hand and foot prints present, may not be clear and could be smudged; in such cases measuring their length can be important evidence linking it to the criminal [8].

Though the most accurate stature estimation method is based on anatomical reconstruction (i.e., the Fully method), followed by type I regression equations (e.g. ordinary least squares-OLS) based on long bones, preferably from the lower limb [9]. The length of the long bones has been consistently used to estimate stature from regression 
equations, but these may be useless when dealing with fresh or decomposed mutilated remains [10]. So attempts have been made to stature estimation from hand and foot length and prints on various Indian and other populations of the world [11-21].

Secular trend is one of the major topics of physical anthropology. The term secular trend is often used to describe a slow continuing change in growth and development over successive generations living in the same territories. Since these changes can be positive, nil or negative, the term 'secular changes is preferred [22]. The term secular trend traditionally indicates the attainment of larger adult body dimensions than in previous generations. According to van Wieringen [23], the term secular changes would be more appropriate: in contrast to secular trend, which suggests a unidirectional course. Secular changes imply the sense of temporal variations among generations or between populations with different geographical and socio-economic backgrounds.

Anthropometric standards are commonly accepted as they vary among different populations and have to be constantly renewed to cope with temporal change [5]. Such changes have been documented in the stature. A secular trend in increase in height has been observed in developed countries since the late 19th century, mainly due to improvement in nutritional status as a result of socioeconomic development [24-26]. Mamidi and associates [25] analyzed secular trend in height in a very large sample from different states of India and reported that, the increments in height for men and women were 0.50 $\mathrm{cm}$ per decade $(\mathrm{p}<0.001)$ and $0.22 \mathrm{~cm}$ per decade $(\mathrm{p}<0.001)$, respectively. Jeong reported a $\mathrm{U}$-shaped secular change pattern in regards to stature in Korean population: the average stature decreased after the Three Kingdom period and increased again in the 20th century [27]. It may be assumed that the similar change would have gone through hand and foot length, but this has never been systematically evaluated. We did not come across any study which has investigated size variations in hand and foot length of temporally different samples. Due to extreme genetic diversity among the Indian population groups, each population group requires a separate study in this regard $[28,29]$. Therefore, the present study aimed to investigate the effects of temporal/secular changes on stature, and hand-foot lengths among Sikh community of Delhi in last 16 years (1998-2015) as well as to examine whether these changes are significant for anthropometric and forensic viewpoint and if so, to provide regression equations for stature estimation for contemporary Sikh population of India.

\section{Materials and Methods}

Sikhs constitute $4 \%$ of the total population of Delhi and maintain genetic entity through marriage pattern and share a common gene pool. The present study included Sikhs (500 males and 500 females) residing in Delhi region of North India with an age range of 19-40 years $[30,31]$. The socioeconomic of strata studied population was medium class, while the recent data was collected by the Kaur [32] (200 males and 200 females) on Ramgarhia Sikh population with an age range of $19-40$ years.

Three parameters i.e., hand-length (HL), foot-length (FL) and stature were measured on the right side of each individual.

Stature (S): It is obtained as a projective distance from floor to the highest point on the head (vertex), when the subject is standing in a standard arm hanging position using anthropometric rod.
Hand Length (HL): It is obtained as a distance between the proximal bracelet crease and dactylion using sliding callipers.

Foot Length (FL): It is obtained as a distance between acropodion and pternion, when the left foot of the subject is placed slightly ahead the right foot and is fully stretched, using rod compass.

Owing to the diurnal variation in stature, individuals were measured in a well-lit room, shoes removed, in an erect position with the shoulders, buttocks and heels lightly touching the wall. Measurements were taken using standard anthropometric instruments in centimeters [33]. All the subjects were healthy and free from any apparent symptomatic deformity. The data was analyzed using SPSS $\mathrm{v}$ 22 package. The data of both the studies were compared to observe secular changes in hand, foot and stature. Linear regression equations for stature estimation were calculated using the above mentioned variables. The regression equations were checked for their accuracy by comparing the estimated stature and actual stature. Keeping in mind that multiplication factor and regression equations are sex and population specific, the sexes have been dealt separately for reconstruction of stature.

\section{Result and Discussion}

The key objective in physical anthropology is to document the vast range of human variability of past and present populations, and to investigate the evolutionary and environmental forces responsible for that variation [26].

Table 1 showed mean values of both the studies. Sex differences were found to be highly significant for all the measurements $(\mathrm{P}<0.01)$ in both studies, which is due to overall larger body structure of male in comparison to females.

A secular trend of decreased sexual dimorphism in studied population has been observed in last 16 years, which is shown by a vast difference of $t$-value in studied variables. This may be related to work discrimination between sexes in sub-recent population (i.e., 1998).

In last 16 years, work discrimination has been decreased. The other possible reason may be related to sample size. An observation of slight decrease of $0.02 \mathrm{~cm}$ among males, and an increase of $0.23 \mathrm{~cm}$ among females over these years is also noted. Foot length (FL), on the other hand showed decrease of $0.09 \mathrm{~cm}$ in case of males and increase of 0.1 $\mathrm{cm}$ in case of female Sikhs of Delhi.

The overall stature of both males and females seemed to decrease in both males and females over the 16 years' time period. In stature, a decrease of $3.1 \mathrm{~cm}$ was observed among male Sikhs whereas decrease of $4.7 \mathrm{~cm}$ was observed among female Sikhs of Delhi. The variation in stature of both the studies has also been demonstrated graphically (Figures 1 and 2).

Most western countries have been reporting not only a secular trend toward increased height, but also a slackening and stabilization of this trend in recent times [34], but our finding is contradictory to this. This negative trend in stature may be associated with lower socioeconomic strata and poor nutrition of 'Ramgarhia'. Alternatively this may be related to a difference in sample size of both study population groups.

Bagga also reported that tendency increasing height either absent or less evident in rural and tribal communities and populations from the less developed countries [34]. It has been established in many previous researches that adult height depends on genetic and environmental factors, and on the interaction between them [35]. 
Silventoinen, provided an excellent review of the factors affecting adult height and mentioned that in modern Western societies, about $20 \%$ of variation in body height is due to environmental variation [36]. $\mathrm{He}$ stated that in poorer environments, this proportion is probably larger, with lower heritability of body height as well as larger socioeconomic body height differences.

The role of childhood environment is seen in the increase in body height during the 20th century simultaneously with the increase in the standard of living. He concluded that the most important non-genetic factors affecting growth and adult body height are nutrition and diseases. Short stature is associated with poorer education and lower social position in adulthood [36]. Family background and other environmental factors in childhood also contribute to this association.

Body height is a good indicator of childhood living conditions, not only in developing countries but also in modern Western societies. All the socio-economic factors suggested that determinants of adult height influence the availability and provision of an adequate diet and the risk of acquiring infections through crowding and poor hygiene. Recently, attention has also been given to substances with estrogen-like actions that are present in nutrients $[22,34,37,38]$.

\begin{tabular}{|l|l|l|l|l|}
\hline Parameter & Study & $\begin{array}{l}\text { Males (cm) } \\
\text { Mean }\end{array}$ & $\begin{array}{l}\text { Females } \\
\mathbf{( c m )} \\
\text { Mean }\end{array}$ & t-test \\
\hline Hand length & Kaur S [31] & 18.7 & 17.0 & 40.09 \\
\cline { 2 - 5 } & Kaur HP [32] & 18.68 & 17.23 & 10.42 \\
\hline \multirow{2}{*}{ Foot length } & Kaur S [31] & 25.7 & 23.1 & 45.96 \\
\cline { 2 - 5 } & Kaur HP [32] & 25.61 & 23.2 & 13.20 \\
\hline \multirow{2}{*}{ Stature } & Kaur S [31] & 170.6 & 158.8 & 37.09 \\
\cline { 2 - 5 } & Kaur HP [32] & 167.54 & 154.1 & 13.1 \\
\hline
\end{tabular}

Table 1: Descriptive statistics showing comparison of two studies (1998 and 2015).

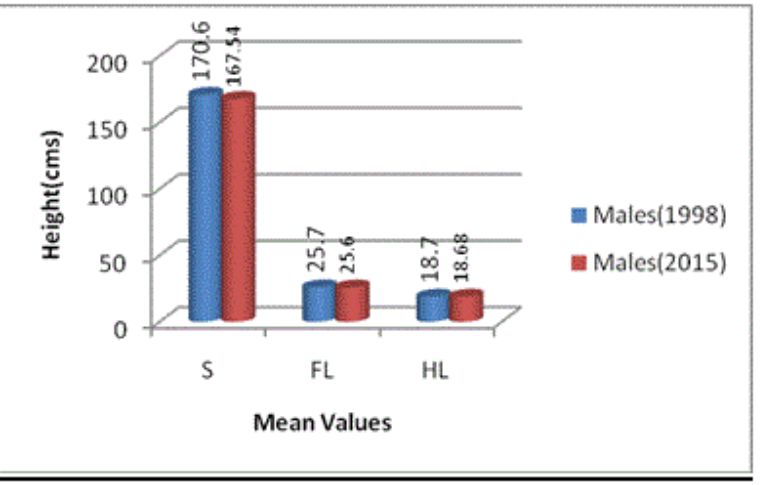

Figure 1: Differences in mean values among male sikhs of two studies.

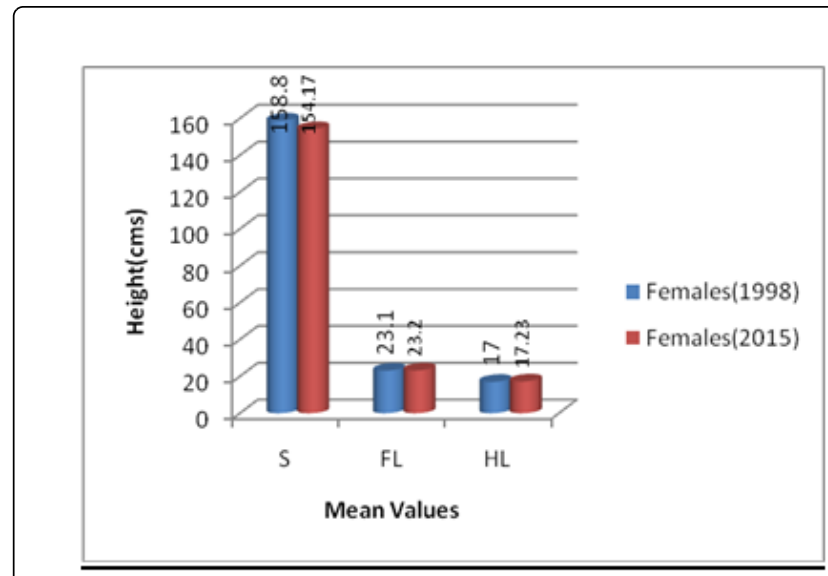

Figure 2: Differences in mean values among female sikhs of two studies.

Table 2 presented the value of coefficient of correlation in the two studies. The correlation coefficient $r$ measures the strength and direction of a linear relationship between two variables (here hand and foot length with stature). The value of $r$ is always between +1 and -1 . Negative (-) value shows downhill linear relationship while positive (+) value shows an uphill linear relationship. A value of \pm 0.70 shows a strong downhill/uphill linear relationship; \pm 0.50 . A moderate downhill or uphill relationship and \pm 0.30 shows a weak downhill or uphill (negative) linear relationship. In both the population groups positive value of $r$ indicates that as the correlation value of hand and foot length increases, their correlation to stature is also increased. In 1998, foot length (FL) exhibited the higher correlation with stature for both males and females, whereas in 2015, hand length showed higher correlation with stature in case of females and foot length showed higher correlation with stature in case of male Sikhs.

\begin{tabular}{|l|l|l|l|}
\hline Parameter & Study & Correlation in Males & Correlation in Females \\
\hline \multirow{2}{*}{ Hand Length } & Kaur S [31] & 0.599 & 0.639 \\
\cline { 2 - 4 } & Kaur HP [32] & 0.593 & 0.591 \\
\hline \multirow{2}{*}{ Foot Length } & Kaur S [31] & 0.671 & 0.696 \\
\cline { 2 - 4 } & Kaur HP [32] & 0.699 & 0.444 \\
\hline
\end{tabular}

Table 2: Comparison of correlation of stature with hand length and foot length of two studies.

Tables 3 and 4 displayed the multiplication factors (M.Fs.) for stature estimation from hand length and foot length respectively for both study groups. The multiplication factor method is a prominent but crude method, which is frequently used for stature estimation sincelong time. It is the ratio of the stature to the respective quantification of bone or body part. A mean multiplication factor thus calculated is utilized for estimating stature in forensic examinations of mutilated/fragmented body part or bone. It is observed that both male and female Sikhs have greater M.F. values for hand and foot length in 1998 study than the 2015 study, which is due to taller stature of subrecent population (i.e., 1998). It has been observed that M.Fs. is usually inverserly proportional to the length of the bone i.e., larger the 
Page 4 of 7

length of bone, smaller the multiplication factor or visa-versa; e.g. M.Fs. for femur is usually in the range of 3.0-4.36; while for tibial length it is 4.0-4.8 (as observed in different Indian studies during literature search); for foot length it is 6.18 to 7.13 ; for hand length the M.F. values vary from 8.95 to 9.24 . These variations in M.Fs clearly show that individuals belonging to the homogeneous genetic composition but inhabiting different or homogeneous geographical locations vary in their body proportions. Due to this, the multiplication factor (i.e., Stature/ Bone length ratio) differs. Further there is a clear denotement that secular trends additionally play a consequential role in this aspect and the multiplication factors formulated on a population must to be revised at least once in a decade to have more preponderant precision in the soothsaid stature among the living populations.

\begin{tabular}{|l|l|l|l|}
\hline S.No & Population/ Region & Author/Year & M.F. \\
\hline 1 & Sikh(F)/Delhi & Kaur S (1998) [31] & 9.24 \\
\hline 2 & Sikh(M)/Delhi & Kaur S (1998) [31] & 9.05 \\
\hline 3 & Sikh(F)/Delhi & Kaur HP (2015) [32] & 8.95 \\
\hline 4 & Sikh(M)/Delhi & Kaur HP (2015) [32] & 8.98 \\
\hline
\end{tabular}

Table 3: Multiplication factor for estimation of stature from hand length in two different studies.

\begin{tabular}{|l|l|l|l|}
\hline S.No & Population/Region & Author/Year & M.F. \\
\hline 1 & Sikh(F)/Delhi & Kaur S (1998) [31] & 6.79 \\
\hline 2 & Sikh(M)/Delhi & Kaur S (1998) [31] & 6.60 \\
\hline 3 & Sikh(F)/Delhi & Kaur HP (2015) [32] & 6.65 \\
\hline 4 & Sikh(M)/Delhi & Kaur HP (2015) [32] & 6.54 \\
\hline
\end{tabular}

Table 4: Multiplication factor for estimation of stature from foot length in two different studies.

The usefulness of these methods is generally assessed on the basis of mean error (error of estimate). But generally the error of estimate is immensely colossal whenever the multiplication factor method is utilized. This may be attributed to the fact that this method utilizes the mean values of stature and measurements and does not take into consideration the range and variation in the data [39].

Table 5 displayed the comparative account of multiplication factors (M.Fs.) for foot length among different living Indian populations. The maximum multiplication factor (7.13) was observed among female Rajputs of Garhwal [40] whereas minimum multiplication factor (6.18) was observed among male Brahmins of Garhwal [41].

\begin{tabular}{|l|l|l|l|}
\hline $\begin{array}{l}\text { S.N } \\
\mathbf{0}\end{array}$ & Population/ region & Author/Year & M.F. \\
\hline 1 & Lodha (F)/W. Bengal & Duggal and Nath (1986) [45] & 6.32 \\
\hline 2 & Lodha (M)/W. Bengal & Duggal and Nath (1986) [45] & 6.45 \\
\hline 3 & Munda (F)/W. Bengal & Duggal and Nath (1986) [45] & 6.26 \\
\hline 4 & Munda (M)/W. Bengal & Duggal and Nath (1986) [45] & 6.24 \\
\hline 5 & Brahmin (F)/GarhwaL,Uttarakhand & Anand (1990) [41] & 6.79 \\
\hline 6 & Brahmin (M)/Garhwal, Uttarakhand & Anand (1990) [41] & 6.18 \\
\hline 7 & Rajput (F)/Garhwal, Uttarakhand & Anand and Nath (1990) [40] & 7.13 \\
\hline 8 & Rajput (M) Garhwal/, Uttarakhand & Anand and Nath (1990) [40] & 6.42 \\
\hline 9 & Rajput (F)/Garhwal L, Sirmour & Kaur S (1996) [46] & 6.71 \\
\hline 10 & Rajput (M)/ Garhwal, Sirmour & Kaur S (1996) [46] & 6.57 \\
\hline 11 & Jat (F)/Churu, Rajasthan & $\begin{array}{l}\text { Nath and Rautray (1996) } \\
\text { [47] }\end{array}$ & 6.68 \\
\hline 12 & Jat (M)/ Churu, Rajasthan & $\begin{array}{l}\text { Nath and Rautray (1996) } \\
\text { [47] }\end{array}$ & 6.6 \\
\hline 13 & Sikh (F)/Delhi & Kaur S (1998) [31] & 6.79 \\
\hline 14 & Sikh (M)/Delhi & Kaur S (1998) [31] & 6.6 \\
\hline 15 & Brahmin (F)/Srinagar & Anand (1998) & 6.68 \\
\hline 16 & Brahmin (M)/Srinagar & Anand (1998) & 6.64 \\
\hline 17 & Sikh (F)/Delhi & Kaur HP (2015) [32] & 6.65 \\
\hline 18 & Sikh (M)/Delhi & 6.54 \\
\hline
\end{tabular}

Table 5: Multiplication factor for foot length measurement among different Indian population.

Table 6 represented the comparative account of regression equations with correlation values for foot length among different living Indian populations [42]. In linear regression, models of the unknown parameters are estimated from the data using linear functions.

Linear regression model refers to an equation wherein if one variable is known, the other can be estimated. In stature estimation by regression analysis method, stature remains the dependent variable and the long bone or a body part as independent variable.

A regression equation thus derived reflects the relationship between the body part and stature [39].

\begin{tabular}{|l|l|l|l|l|l|l|}
\hline S.No & Population & Sex & Area & Author/Year & Regression Equation & Value of ' $r$ ' \\
\hline 1 & Sikh & F & Delhi & Kaur S (1998) [31] & H = 78.73+3.40 FL & 0.696 \\
\hline 2 & Sikh & M & Delhi & Kaur S (1998) [31] & H = 79.73+3.51 FL & 0.671 \\
\hline 3 & Brahmin & F & Himachal Pradesh & Nath et. al (2001) & H = 93.56+2.60 FL & 0.467 \\
\hline 4 & Rajputs & M & Himachal Pradesh & Krishan (2006) & H = 68.085+4.054FL & 0.732 \\
\hline
\end{tabular}


Citation: Kaur S, Saini V (2016) Secular Changes on Stature Reconstruction from Hand and Foot Dimensions among Sikhs of Delhi. J Forensic

Page 5 of 7

\begin{tabular}{|c|c|c|c|c|c|c|}
\hline 5 & Rajputs & $\mathrm{F}$ & Himachal Pradesh & Krishan (2006) & $\mathrm{H}=71.941+3.703 \mathrm{FL}$ & 0.739 \\
\hline 6 & Gujjars & M & North India & Krishan \& Sharma (2007) [11] & $H=88.58+3.255 \mathrm{FL}$ & 0.86 \\
\hline 7 & Gujjars & M & North India & Kanchan et al. (2008)[43] & $H=88.116+3$ & 0.75 \\
\hline 8 & Gujjars & M & North India & Kanchan et al. (2008) [43] & $H=95.202+2.737 \mathrm{LFL}$ & 0.704 \\
\hline 9 & Gujjars & $\mathrm{F}$ & North India & Kanchan et al. (2008) [43] & $\mathrm{H}=106.709+2.219 \mathrm{RFL}$ & 0.558 \\
\hline 10 & Gujjars & $\mathrm{F}$ & North India & Kanchan et al. (2008) [43] & $\mathrm{H}=104.302+2.324 \mathrm{LFL}$ & 0.536 \\
\hline 11 & Shia Muslims & M & North India & Bhavana et al. (2009) & $H=119.74+1.98 \mathrm{FL}$ & 0.546 \\
\hline 12 & Shia Muslims & $\mathrm{F}$ & North India & Bhavana et al. (2009) & $\mathrm{H}=104.25+2.22 \mathrm{FL}$ & 0.538 \\
\hline 13 & Kaniyas & M & Karnataka & Imtiazul Haq (2010) & $\mathrm{H}=80.130+3.31 \mathrm{FL}$ & - \\
\hline 14 & Kaniyas & $\mathrm{F}$ & Karnataka & Imtiazul Haq (2010) & $\mathrm{H}=94.73+2.46 \mathrm{FL}$ & - \\
\hline 15 & Dungris Garasiya & M & Karnataka & Imtiazul Haq (2010) & $\mathrm{H}=107.05+2.31 \mathrm{FL}$ & - \\
\hline 16 & Dungris Garasiya & $\mathrm{F}$ & Karnataka & Imtiazul Haq (2010) & $\mathrm{H}=75.58+3.379 \mathrm{FL}$ & - \\
\hline 17 & Sikhs & M & Delhi & Kaur (2015) [32] & $\mathrm{S}=63.31+4.07 \mathrm{FL}$ & 0.488 \\
\hline 18 & Sikhs & $\mathrm{F}$ & Delhi & Kaur (2015) [32] & $\mathrm{S}=100.67+2 . .31 \mathrm{FL}$ & 0.198 \\
\hline
\end{tabular}

Table 6: Regression equations obtained for foot length measurements among different Indian population.

The maximum correlation (0.750) was observed among male Gujjars of North India [43] whereas minimum correlation (0.028) was observed among female Sikhs of Delhi [33].

Table 7 represented the comparative account of multiplication factors and regression equations for hand length in both males and females on different living Indian population [44]. The greatest M.F. of $9.24 \mathrm{~cm}$ was observed among female Sikhs of Delhi [31] whereas least M.F. of $8.95 \mathrm{~cm}$ was observed among female Sikhs of Delhi [33].
In 2012, Krishan and associates [39] conducted a comparative study to estimate the stature from the multiplication factors and regression analysis to find the error in estimated stature. Their results indicated that the range of error in estimation of stature from regression analysis method is less than that of multiplication factor method.

Thus, they confirmed that the regression analysis method is better than multiplication factor analysis in stature estimation.

\begin{tabular}{|c|c|c|c|c|c|c|c|}
\hline S. No. & Population & Area & Author & Year & Sex & Regression Equation & Multiplication Factor \\
\hline \multirow{2}{*}{1} & \multirow{2}{*}{ Punjabi } & \multirow{2}{*}{ Delhi } & \multirow{2}{*}{$\begin{array}{l}\text { Nath, Rajni and Chhibber } \\
\text { [48] }\end{array}$} & \multirow{2}{*}{1990} & M & - & - \\
\hline & & & & & $\mathrm{F}$ & $\mathrm{S}=85.22+4.05 \mathrm{HL}$ & 9.12 \\
\hline \multirow[b]{2}{*}{2} & \multirow[b]{2}{*}{ Sikhs } & \multirow[b]{2}{*}{ Delhi } & \multirow[b]{2}{*}{ Kaur S [31] } & \multirow{2}{*}{1998} & M & $\mathrm{S}=89.13+4.31 \mathrm{HL}$ & 9.05 \\
\hline & & & & & $\mathrm{F}$ & $\mathrm{S}=88.64+4.04 \mathrm{HL}$ & 9.24 \\
\hline \multirow{2}{*}{3} & \multirow{2}{*}{ Delhi } & \multirow{2}{*}{ Delhi } & \multirow{2}{*}{$\begin{array}{l}\text { Sunil Dikshit, Aggarwal, } \\
\text { Rani [49] }\end{array}$} & \multirow{2}{*}{2005} & M & $\mathrm{S}=85.84+4.32 \mathrm{HL}$ & - \\
\hline & & & & & $\mathrm{F}$ & $\mathrm{S}=80.94+4.40 \mathrm{HL}$ & - \\
\hline \multirow[b]{2}{*}{4} & \multirow{2}{*}{ Punjabi } & \multirow[b]{2}{*}{ Delhi } & \multirow[b]{2}{*}{ Sethi and Nath [50] } & \multirow[b]{2}{*}{2000} & M & - & - \\
\hline & & & & & $\mathrm{F}$ & $\mathrm{S}=88.04+2.95 \mathrm{HL}$ & 8.99 \\
\hline \multirow{2}{*}{5} & \multirow{2}{*}{ North Indian } & \multirow{2}{*}{ North India } & \multirow{2}{*}{ Manpreet Kaur et al. } & \multirow{2}{*}{2011} & M & $\mathrm{S}=130.90+2.398 \mathrm{HL}$ & - \\
\hline & & & & & $\mathrm{F}$ & $\mathrm{S}=160.41+0.027 \mathrm{HL}$ & - \\
\hline \multirow{2}{*}{6} & \multirow{2}{*}{ Sikhs } & \multirow{2}{*}{ Delhi } & \multirow{2}{*}{ Kaur HP [32] } & \multirow{2}{*}{2015} & M & $\mathrm{S}=85.73+4.38 \mathrm{HL}$ & 8.98 \\
\hline & & & & & $\mathrm{F}$ & $\mathrm{S}=81.7+4.21 \mathrm{HL}$ & 8.95 \\
\hline
\end{tabular}

Table 7: Regression equations and multiplication factors obtained on hand length by various authors. 
Decline in linear body dimensions with age has been reported in studies throughout the world. There is sufficient evidence that a portion of the changes in stature in a cross-sectional study may be due to secular trend rather than ageing [34].

\section{Conclusions}

The process of human identification requires the completion of multiple stages of investigation and the combination of various evidentiary threads which may lead to a putative identity of the deceased. Only once a presumptive identification has been made, can confirmation of identity be sought through the use of DNA or any other primary source of identity [45].

The secular trend observed over the years, for both male and female stature decreased sharply, for which alternative historical explanations proposed are related to differential migration and survival. Population variations in somatometric dimensions do exist and are attributed to genetic, dietary habits and environmental factors. The insignificant differences in secular trends in hand and foot dimensions indicate these somatometric changes are highly population specific. Therefore specific formulae or regression equations used in prediction of stature are only applicable to the population from which the data were collected. Further these formulae should always be updated [9].

The conclusions from the present study can be furnished as:

- The Male Sikhs have greater hand and foot dimensions than female Sikhs including stature for both the studies.

- The correlation values revealed that both hand and foot dimension exhibit positive correlation with stature.

- In both the studies, among males, the highest correlation coefficient is indicated for foot length with stature thereby suggesting highest reliability and accuracy in estimating stature.

- Among females, earlier study (1998) showed highest correlation for foot length whereas recent study (Kaur [32]) showed highest correlation between hand length and stature.

- Based on the positive and moderate to high correlation between hand and foot dimensions and stature, among male and female Sikhs of Delhi, linear regression equations have been formulated. Previously increase in the body height has been mentioned by several authors but present study showed a decrease (negative secular change) in body height in last 16 years among Sikh population of Delhi.

\section{References}

1. https://en.wikipedia.org/wiki/Neeraj_Grover_murder_case

2. https://en.wikipedia.org/wiki/2006_Noida_serial_murders

3. Zeybek G, Ergur I, Demiroglu Z (2008) Stature and gender estimation using foot measurements. Forensic Sci Int 181: 54.e1-54.e5.

4. Kaur M, Singh B, Mahajan A, Khurana BS, Kaur A, et al. (2013) Anthropometric measurements of hand length for estimation of stature in North Indians. International Journal of Applied Biology and Pharmaceutical Technology 4: 251-155.

5. Khairulmazidah M, Nurul Nadiah AB, Rumiza AR (2013) Stature Estimation Using Foot and Shoeprint Length of Malaysian Population. World Academy of Science, Engineering and Technology International Journal of Medical, Health, Biomedical, Bioengineering and Pharmaceutical Engineering 7: 365-368.

6. Davies CM, Hackman L, Black SM (2014) The foot in forensic human identification. The Foot 24: 31-36.
7. Kanchan T, Sinha S, Krishan K (2015) Is there a correlation between footstep length, lower extremities, and stature? J Forensic Sci 60: 1337-1340.

8. Auerbach BM, Ruff CB (2010) Stature estimation formulae for indigenous North American populations. Am J Phy Anthropol 141: 190-207.

9. Pablos A, Gómez-Olivencia A, García-Pérez A, Martínez I, Lorenzo C, et al. (2013) From toe to head: use of robust regression methods in stature estimation based on foot remains. Forensic Sci Int 226: 299.e1-299.e7.

10. Marinho L, Almeida D, Santos A, Cardoso HF (2012) Is the length of the sternum reliable for estimating adult stature? A pilot study using fresh sterna and a test of two methods using dry sterna. Forensic Sci Int 220: 292.el-292.e4.

11. Krishan K, Sharma A (2007) Estimation of stature from dimensions of hands and feet in a North Indian population. J Forensic Legal Med 14: 327-332.

12. Sen J, Ghosh S (2008) Estimation of stature from foot length and foot breadth among the Rajbanshi: an indigenous population of North Bengal. Forensic Sci Int 181: 55-56.

13. Chikhalkar BG, Mangaonkar AA, Nanandkar SD, Peddawad RG (2010) Estimation of Stature from Measurements of Long Bones, Hand and Foot Dimensions. J Indian Acad Forensic Med 32: 329-331.

14. Jakhar JK, Pal V, Paliwal PK (2010) Estimation of Height from Measurements of Foot Length in Haryana Region. J Indian Acad Forensic Med 32: 231-233.

15. Moorthy TN, Mostapa AMP, Boominathan R, Raman N (2014) Stature estimation from footprint measurements in Indian Tamils by regression analysis. Egyptian J Forensic Sciences 4: 7-16.

16. Shah RK, Patel JP, Patel BG, Kanani SD, Patel MD (2014). Estimation of stature from foot length and hand length measurements in Gujarat region. NJIRM 5: 16-19.

17. Patel JP, Patel PG, Shah RK, Bhojak NR, Desai JN (2014) Estimation of stature from hand length in Gujarat region. NHL Journal of Medical Sciences 3: 41-44.

18. Abledu JK, Abledu GK, Offei EB, Antwi EM (2015). Determination of Sex from Footprint Dimensions in a Ghanaian Population. PLoS One 10: e0139891.

19. Agarwal S, Zaidi SHH, Agarwal SK (2015) Correlation of body height by foot length and knee height measurements in population of North India. Int J Anat Res 3: 1225-1229.

20. Geetha GN, Swathi, Athavale SA (2015) Estimation of stature from hand and foot measurements in a rare tribe of Kerala state in India. J Clin Diagn Res 9: HC01-HC04.

21. Supare MS, Pandit SV, Bagul AS (2015) Estimation of stature from hand length and hand breadth in medical students of Maharashtra, India. 4: 154-159.

22. De Muinich Keizer SM, Mul D (2001) Trends in pubertal development in Europe. Hum Reprod Update 7: 287-291.

23. van Wieringen JC (1986) Secular growth changes. In Falkner, F. and Tanner, J.M. (eds.) Human Growth: A comprehensive Treatise Plenum Press, New York pp: 3-331.

24. Vargas DM, Fernando GLA, Ana SS (2010) the secular trend of growth in height in Blumenau, Brazil and its relationship with the human development index (hdi). Rev Assoc Med Bras 56: 304-308.

25. Mamidi RS, Kulkarni B, Singh A (2011) Secular trends in height in different states of India in relation to socioeconomic characteristics and dietary intakes. Food Nutr Bull 32: 23-34.

26. Sarajlić N, Resić E, Gradaščević A, Salihbegović A, Balažic J, et al. (2014) Secular trends in body height in Balkan populations from 1945 to 1995. Bosn J Basic Med Sci 14: 209-213.

27. Jeong, Yangseung (2014) "Secular change in stature and body mass in Korea over the last two millennia." PhD diss, University of Tennessee.

28. Saini V, Srivastava R, Rai RK, Shamal SN, Singh TB, et al. (2011) An osteometric study of Northern Indian populations for sexual dimorphism in Craniofacial Region. J Forensic Sci 56: 700-705 
29. Srivastava A, Yadav VK (2014) Reconstruction of Stature using Hand and Foot Dimensions among Indian Population. J of Engineering Sciences and Emerging Technologies 6: 400-404.

30. Kaur S, Nath S (1997) Reconstruction of stature from various dimensions of upper extremity among Sikh females of Delhi. Proceedings of X All India Forensic Science Conference, Bhubaneswar pp: 6-16.

31. Kaur S (1998) Estimation of Stature from Different Body dimensions among male and female Sikh of Delhi. Unpublished thesis, University of Delhi.

32. Kaur HP (2015) Determination of stature from hand and foot dimensions in the 'Ramgarhia' Sikh population of Delhi. Unpublished dissertation, NICFS, Delhi.

33. Singh IP, Bhasin MK (2004) A Manual of Biological Anthropology, Delhi. Kamal-Raj Enterprises.

34. Bagga A (2013) Age changes in some linear measurements and secular trend in height in adult Indian women. Acta Biologica Szegediensis 57: 51-58.

35. Tomljanovic BA, Ristic S, Milic BB, Ostojic S, Gombac E, et al. (2004) Secular change in body height and cephalic index of Croatian medical students (University of Rijeka). Am J Phys Anthropol 123: 91-96.

36. Silventoinen K (2003) Determinants of variation in adult body height. J Biosoc Sci 35: 263-285.

37. Gigante DP, Horta BL, Lima RC, Barros FC, Victora CG (2006) Early life factors are determinants of female height at age 19 years in a populationbased birth cohort (Pelotas, Brazil). J Nutr 136: 473-478.

38. Maria ED, Emanuel S (2008) Secular changes in human biological variables in Western Countries: an updated review and synthesis. J Anthropol Sci 86: 91-112.

39. Krishan K, Kanchan T, Sharma A (2012) Multiplication factor versus regression analysis in stature estimation from hand and foot dimensions. J Forensic Leg Med 19: 211-214.

40. Anand, Nath S (1990) Estimation of stature through percutaneous measures of upper and lower extremities among Rajputs of Pauri, Garhwal. Ind J For Sci 5: 83-89.
41. Anand (1990) Use of percutaneous measures of body in reconstruction of stature: A forensic anthropological study of Brahmins and Rajputs of Pauri (U.P.). Unpublished Master's Dissertation, University of Delhi.

42. Bhavna, Nath S (2008) Use of Lower limb measurements in reconstructing stature among Shia Muslims. The Internet Journal of Biological Anthropology.

43. Kanchan T, Menezes RG, Moudgil R, Kaur R, Kotian MS, et al. (2008) Stature estimation from foot dimensions. Forensic Sci Int 179: 241.

44. Maclaughlin-Black S, Gunstone A (1995) Early fetal maturity assessed from patterns of ossification in the hand and foot. Int J Osteoarchaeo 5: 51-59.

45. Duggal and Nath (1986) Estimation of stature using percutaneous length of radius, ulna and tibia among Lodhas and Mundas of district Midnapore, West Bengal. Anthropologie 24: 23-27.

46. Kaur S (1996) Reconstruction of stature through measurements of upper and lower extremities among male and female Rajputs of Sirmour District, Himachal Pradesh. Unpublished Master's Dissertation, Univ of Delhi.

47. Nath, Rautray (1996) Estimation of stature from bone dimensions of upper limb among Jats of Churu, Rajasthan. The Indian Journal of Criminology and Criminalistics 27: 85-91.

48. Rajni NS, Chhibber S (1990) Reconstruction of stature from percutaneous length of upper and lower extremity segments among Punjabi females of Delhi. Indian J Forensic Sci 4: 171-181.

49. Sunil, Dikshit PC, Aggarwal A, Rani M (2005) Estimation of stature from Hand length. J Indian Acad Forensic Med 27: 219-221.

50. Sethi V, Nath S (2000) Estimation of stature through Hand and Foot lengths among Punjabi females of Delhi. South Asian Anthropologist 21: 67-71. 